\title{
CONFLICT BETWEEN WORK AND FAMILY ROLES AND SATISFACTION AMONG NURSES IN DIFFERENT SHIFT SYSTEMS IN CROATIA: A QUESTIONNAIRE SURVEY
}

\author{
Ana ŠIMUNIĆ and Ljiljana GREGOV \\ Department of Psychology, University of Zadar, Zadar, Croatia \\ Received in October 2012 \\ CrossChecked in January 2012 \\ Accepted in April 2012
}

\begin{abstract}
The objective of this study was to examine the perception of conflict between work and family roles and job, family, and life satisfaction among nurses in Croatia. One hundred and twenty-nine nurses (married mothers) working in hospitals in Zadar, Šibenik, and Split were divided in four groups according to their worktime schedule. The participants completed a survey, which included a set of sociodemographic-type questions, questions about the level and allocation of family responsibilities between spouses, and scales measuring the perceived negative effects of worktime, psychological demands of the work, work-family conflict, and semantic differential scales for measuring the affective and cognitive-evaluative component of job, family, and life satisfaction. This was the first study in Croatia to deal with work-family conflict among nurses or workers with different shift systems.

The results of this study indicate that nurses working morning shifts only experienced less conflict between work and family than other groups of nurses, who worked the morning, afternoon, and the night shift. The cognitive-evaluative component of job satisfaction was the highest among morning shift nurses and the lowest in nurses who worked 12-hour shifts, while the affective component of life satisfaction was the lowest in nurses working irregular and backward rotated shifts. These results confirm that shiftwork makes the work-family role conflict even worse. They also support the view that the type of shift rotation matters.
\end{abstract}

KEY WORDS: family satisfaction, job satisfaction, life satisfaction, nursing, shiftwork, work-family conflict

\section{Women and worktime stress}

Although the number of working women is increasing and attitudes about gender roles are changing, the society still expects women to take responsibility for most childcare and household tasks (1). Research results show that women indeed see themselves as more responsible for the family domain than men (2). This "woman's work" often takes priority over other duties and can not be delayed (3). Studies show that levels of stress hormones such as epinephrine, norepinephrine, and cortisol remain high in women after the work day is over, women with children in particular (4). Certain types of work schedules can be a significant stressor for a working mother. For example, shift work has been shown to have negative effects on physical health, sleep quality, and mental health (5-7). 
The problems of shift workers derive from having to work with inadequate levels of 'stress' hormones such as cortisol and catecholamine, which can have a more rapid impact on health than prolonged exposure to stressful events (8). Shift work has many effects on nurses' health. For example, the risk of breast cancer and metabolic syndrome is higher among nightshift workers (9-11). The risks of making an error at work were significantly increased when work shifts were longer than twelve hours, when nurses worked overtime, or when they worked more than forty hours per week (12). Extended daily working hours have both negative (example fatigue) and positive effects (more time for the family, social life, and domestic duties) (13-17).

Women are particularly susceptible to interrole conflict, which refers to the experience of multiple, conflicting expectations from different people. Increased workload cancels opportunities for relaxation and threatens the physical and mental health of women.

\section{Conflict between work and family roles and worktime schedules}

Different roles can affect each other if performed at the same time. This interaction can be complementing or conflicting and can become a source of stress when the roles are not compatible or when they exceed the capabilities of an individual. Since two important focal points of adult life are family and work, most research has dealt with the interaction between these two domains (18): conflict due to the disrupting interference of work to family life (work-to-family conflict) and conflict due to the disrupting interference of family to work life (family-to-work conflict).

Today's almost universally accepted so-called integrative model of conflict between work and family roles suggests that the structural, social, and psychological demands of work and family contribute to increasing levels of work-family conflict by increasing demands at work and workto-family conflict and increasing demands of the family and family-to-work conflict $(18,19)$. This source of stress leads to distress/dissatisfaction with work and family, and these two forms of distress cause general discontent and depression in particular.

Structural work requirements, such as shift work (20) and extended working hours $(21,22)$, as well as social and psychological demands, such as the amount of responsability, a variety of tasks, workload, and psychological pressure, are associated with a higher degree of work-to-family conflict, with important consequences such as the subjective experience of work stress, work dissatisfaction, and poor functioning at work $(23,24)$. Likewise, structural and social requirements of the family (number and age of children, care for children, care for elders, marital status, quality of family member relationships) were associated with higher levels of family-to-work conflict $(25,26)$, with important consequences such as the subjective feeling of family stress, dissatisfaction with family and fatigue, inefficiency in marital and parenting functions $(19,23)$.

One study showed that shift workers, in comparison with daily workers, had a greater amount of work interference with family life (workto-family conflict), and the amount of interference increased with time (27). However, an impact on family-to-work conflict can not be excluded. Shift workers may sacrifice sleep quality to spend more time with the family, and thereby diminish their efficiency at work.

As the type of shift rotation also affects workers' well-being (28-31), it should be taken into account in studying the work-family conflict. Grosswald (32) found that work-to-family spillover was the highest in workers with the rotating shift system in comparison with those in permanent night shifts, permanent afternoon shifts, and split shifts. It is not difficult to understand why rotating shift systems have a negative impact on household and family duties. Even childcare becomes a big problem, as it is needed at different times of the day. Moreover, in a 32-month follow-up, Amelsvoort et al. (33) found that employees in the backward rotating shift system have a greater need for recovery, poorer health status, poorer sleep quality, and greater work and family interrole conflict than forward rotating shift workers.

Research conducted on nurses gave similar results $(34,35)$. Workload and irregular work-time schedules were significant predictors of work-tofamily conflict, and the conflict between work and family roles was associated with lower levels of job and life satisfaction. The issue has been studied thoroughly through the European Nurses Early Exit Study (NEXT) (36), whose aim is to see why nurses leave their profession early, often earlier than other professions. The NEXT study has included more than 77,000 nurses in 10 European countries. They 
concluded that attempts to retain nurses in their profession should take into consideration the workto-family conflict (WFC), the regularity of working time in particular, and overtime issues.

\section{Study objective}

Very little research has been done on the conflict between work and family roles in societies like ours, where most women still assume the traditional homemaking role. This points to an increased risk of a conflict between women's professional role and her role as a mother and a housewife. If their job includes shiftwork, which tends to affect many aspects of life and involve problems such as sleep disturbances, fatigue, lower performance, and disturbed family and social relationships, this conflict can be even more pronounced. Additional sources of stress such as understaffed night shifts and overnight patient crises put even more strain on the work-to-family conflict and satisfaction with job, family, and life.

The objective of this study was to establish the perception of the conflict between work and family roles and life satisfaction among nurses in Croatia working different shifts. This is the first research of the kind in Croatia.

\section{SUBJECTS AND METHODS}

\section{Participants}

The study included 128 married nurses (all having children) from the General Hospital in Zadar and Šibenik and Clinical Hospital Center in Split, as our focus was on the conflict between work and family roles. They were between 19 and 59 years old and worked shifts which rotated every two days (socalled fast-rotating shifts), as follows:

- Forward rotation (morning-afternoon-nightday off), 8 hours $(\mathrm{N}=37)$

- Backward rotation (night-morning-afternoonday off), 8 hours ( $\mathrm{N}=29) 1$

- Forward rotation (day, night, day off), 12 hours $(\mathrm{N}=25)$

\footnotetext{
${ }^{1}$ A group of nurses working in irregularly organized shifts were included here, since frequent change of there rapidly changing shifts is most similar to a backward rotation shift system.
}

- The fourth was the control group of nurses working only the eight-hour morning shift $(\mathrm{N}=37)$.

\section{Questionnaires and response evaluation}

We used a questionnaire, which opened with a set of sociodemographic questions about the participant age, education, marital status, number of children, overall years of service at the current workplace, the type of shifts they worked, and overtime work. There were also three questions about the level and distribution of responsibilities in childcare and housework between the spouses.

A Scale of the psychological demands of work used for this study included 12 items about the autonomy of the job, role conflict, role ambiguity, and work overload. Examples of the items are: "I have enough materials and the necessary instruments to perform my job properly" and "I have enough time to complete my job". The reliability of this scale, expressed with Cronbach's alpha coefficient, was 0.78 . The participants were asked to rate their responses on a seven-point scale (1-strongly disagree, 7-strongly agree). Higher score indicates a higher level of perceived psychological demands. The average scores ranged from 1.4 to 6.9.

The Scale of the negative effects of worktime is an adapted translation of the original scale by Ahasan et al. (37). It covers effects of worktime on family life, social life, and health, with questions such as "My worktime disturbs my family life" or "My worktime restricts my social life". Scale reliability, expressed with Cronbach's alpha coefficient, was 0.89 . The participants were to rate their responses on a seven-point scale (1-strongly disagree, 7-strongly agree). Higher score reflects a higher level of perceived negative effects of shift organisation on family and social life and general health. The scores ranged from 1 to 7 .

The translated and modified Conflict between work and family roles scale developed by Netemeyer et al. (38) was used for measuring the perceived level of conflict between work and family roles, taking into account time and strain as the causes of conflict. It consists of two sets of six items, the first focusing on the work-to-family conflict (WFC; example: "Due to the time needed for my job, I do not have enough time to participate in family activities") and the second on the family-to-work conflict (FWC; example: "Due to the time spent for family activities, I often have to delay and modify 
my work activities"). Reliabilities were satisfactory (around 0.8). Again the participants rated their responses on a seven-point scale (1-strongly disagree, 7-strongly agree) and higher scores reflected a greater level of perceived negative impact of work on family and vice versa. The scores on the WFC scale ranged from 1 to 7 and on the FWC scale from 1 to 6.8 .

Semantic differential items for measuring job, family, and life satisfaction were developed by Gregov (39). Each semantic differential item consisted of bipolar pairs of adjectives listed on opposite ends of seven-point scale ranging from -3 to +3 . Affective and cognitive-evaluational components of satisfaction were determined for all three domains (job, family, life). The affective component of job satisfaction (ACJS) included 13 items and the cognitive-evaluational component (CCJS) seven. The affective component of satisfaction with the family (ACFS) included 14 items and cognitive-evaluative component (CCFS) five. Finally, the affective component of life satisfaction (ACLS) included 14 items and the cognitive-evaluative component (CCLS) five.

The reliabilities of these components were all satisfactory, with Cronbach's alpha coefficients ranging from 0.82 to 0.96 . To evaluate the -3 to +3 range scores we had to recode them into the 1 to 7 range, in which 1 corresponded to the adjective indicating the most negative attitude and 7 to the adjective indicating the most positive attitude. In other words, the higher the score the greater the satisfaction. The score ranges were as follows: for ACJS from 1.8 to 7 , for CCJS from 1 to 7 , for ACFS from 4 to 7, for CCFS from 1 to 7, for ACLS from 2.2 to 7 , and for CCLS from 1 to 7.

\section{Data collection}

First we contacted hospital directors and head nurses by phone to obtain their consent to carry out the study. Department head nurses were contacted in person to help distribute the questionnaires. We aimed for married nurses to make the majority of the sample and for an equal distribution of questionnaires between shift types.

The questionnaires were distributed and returned in envelopes for the sake of anonymity and greater sincerity in responses. One of the researchers collected them in person from each participant from February to March 2008. The response rate was about $80 \%$, which is relatively high. Out of 174 questionnaires collected results of 128 nurses who were married we used for the purpose of this study.

\section{Ethical approval}

This research was approved by the Ethics Committee for research in psychology of the University of Zadar. It followed the ethical principles of the Croatian Psychological Society, which are in accordance with the ethical principles of the American Psychological Association and the British Psychological Society.

\section{RESULTS AND DISCUSSION}

\section{Sociodemographic profile of nurses in different shift systems}

Table 1 shows that the groups of nurses did not differ in the years of service at the current workplace. Nurses working the morning shift alone were on average significantly older and had more years of service than the nurses working 12-hour shifts. There were more nurses with higher education in the morning shift group than in the other groups (chi-square $=5.07 ; p=0.024)$. Furthermore, nurses working morning shifts alone less often reported overtime work than the nurses working 12-hour shifts (chi-square=7.24; $\mathrm{p}=0.007$ ). These differences should be taken into account when interpreting the differences in work-to-family conflict and satisfaction. Parkes (40) suggests that older shift workers experience more problems than younger shift workers, because the circadian adaptation declines with age. It is therefore possible that most of the workers who now work the morning shift alone worked the night shift before, and were transferred to the morning shift because of accumulated health problems.

\section{Perceived job characteristics and family responsibilities}

Earlier studies suggest that housework and the care for children and the elderly are related to family-to-work conflict and the level of stress in families $(18,27)$. In our study, we observed no differences in these family tasks between the nurse groups.

Perceived psychological demands of work have previously been shown to correlate with stress 
Table 1 Sociodemographic characteristics of nurses working different shifts.

\begin{tabular}{|c|c|c|c|c|c|c|c|c|c|c|}
\hline \multirow{3}{*}{ Variable } & \multicolumn{8}{|c|}{ Form of shift organization } & & \\
\hline & \multicolumn{2}{|c|}{$\begin{array}{l}\text { Morning } \\
\text { shift only }\end{array}$} & \multicolumn{2}{|c|}{$\begin{array}{l}\text { Forward } \\
\text { rotation, } \\
\text { 12-hour } \\
\text { shifts }\end{array}$} & \multicolumn{2}{|c|}{$\begin{array}{c}\text { Forward } \\
\text { rotation, } \\
\text { 8-hour shifts }\end{array}$} & \multicolumn{2}{|c|}{$\begin{array}{c}\text { Backward } \\
\text { rotation plus } \\
\text { irregular } \\
\text { 8-hour shifts }\end{array}$} & \multicolumn{2}{|c|}{$\begin{array}{c}\mathrm{df}=3 / 128- \\
3 / 124\end{array}$} \\
\hline & M & sd & M & sd & M & sd & M & sd & $\mathbf{F}$ & $\mathbf{p}$ \\
\hline Age / years & 44.54 & 7.99 & 36.96 & 5.75 & 40.25 & 8.57 & 39.17 & 8.78 & 5.08 & 0.002 \\
\hline Total work experience / years & 24.08 & 8.41 & 16.28 & 5.89 & 19.54 & 8.59 & 17.61 & 9.22 & 5.53 & 0.001 \\
\hline Current service / years & 12.32 & 9.22 & 11.29 & 7.79 & 13.95 & 9.25 & 12.59 & 9.22 & 0.46 & 0.709 \\
\hline Overtime per week / hours & 0.92 & 2.69 & 3.32 & 5.63 & 1.86 & 4.16 & 1.37 & 4.12 & 1.76 & 0.158 \\
\hline Number of children & 2.05 & 0.71 & 1.96 & 1.06 & 2.14 & 0.98 & 2.14 & 0.99 & 0.23 & 0.875 \\
\hline
\end{tabular}

$M=$ mean

$s d=$ standard deviation

$F=$ F-ratio

$d f=$ degrees of freedom

experienced at work and with work-to-family conflict $(18,35)$. Nurses who worked morning shifts alone estimated psychological demands of work and the negative effects of worktime on social and family life, and general health significantly lower than the other three groups of nurses (Table 2). This was expected, given that earlier studies show greater negative effects of night and shift work on health status (6) and on family and social life (42). Working night shifts requires extra effort to stay awake and be effective; this alone puts a lot of stress on the body and can cause health problems and fatigue. Moreover, night shifts are often not aligned with the worktime and the responsibilities of other family members, friends, and the social environment in general.

In addition, morning shift nurses were the oldest group of nurses. A number of them might have been transferred from shiftwork to permanent morning shifts because their capability to adapt to circadian changes and other role-related demands declined with age.

\section{Work-to-family and family-to-work conflict}

Morning shift nurses perceived the level of workto-family conflict significantly lower from the other three groups (Table 2). This is consistent with earlier research that established a correlation between nightshifts and work-to-family conflict $(3,35)$.

On the other hand, the groups did not significantly differ in the level of family-to-work conflict (Table 2 ), which is not surprising considering that these groups share similar sources of stress in the family (at least those taken account in this research) and considering the results of previous studies which show the same $(19,23,25)$. The average perceived level of family-to-work conflict was very low, especially in comparison with work-to-family conflict. It is possible that this is related to the importance of the family for women in Croatia and to their traditional family roles. Again, the age difference should be taken into account, since it is very likely that the morning shift nurses have older children, who are not so dependent any more, and their obligations at home are fewer.

\section{Satisfaction with work, family, and life}

Morning shift nurses had the highest and 12-hour forward rotating shift nurses the lowest scores on the scale of the cognitive-evaluative component of job satisfaction. This means that, while nurses are generally happy with their jobs (the average affective component of job satisfaction was 5 points on the assessment scale), the nurses on 12-hour shifts have a more negative attitude toward shift organisation, as they not only have to work shifts but also work longer hours and thus feel more fatigued (43).

No significant differences were observed between the groups in the cognitive or affective components of satisfaction with family life (Table 2). This supports the findings by Mott et al. (44) who showed that, shift work does not significantly affect the level of marital and family happiness.

Concerning life satisfaction the significant difference between nurses was found for its affective component (Table 2). Nurses working backward 
Table 2 Descriptive parameters and one-way analyses of some perceived characteristics and aspects of family, work, and life in general in nurses with different forms of shift organization

\begin{tabular}{|c|c|c|c|c|c|c|c|c|c|c|}
\hline \multirow{4}{*}{ Variable } & \multicolumn{8}{|c|}{ Form of shift organization } & \multirow[b]{4}{*}{$\mathbf{F}$} & \multirow[b]{4}{*}{$\mathbf{p}$} \\
\hline & \multicolumn{2}{|c|}{$\begin{array}{l}\text { Morning shift } \\
\text { only }\end{array}$} & \multicolumn{2}{|c|}{$\begin{array}{c}\text { Forward } \\
\text { rotation, 12- } \\
\text { hour shifts }\end{array}$} & \multicolumn{2}{|c|}{$\begin{array}{l}\text { Forward } \\
\text { rotation, } \\
\text { 8-hour shifts }\end{array}$} & \multicolumn{2}{|c|}{$\begin{array}{l}\text { Backward } \\
\text { rotation plus } \\
\text { irregular } \\
\text { 8-hour shifts }\end{array}$} & & \\
\hline & \multicolumn{2}{|c|}{$\mathbf{N}=\mathbf{3 7}$} & \multicolumn{2}{|c|}{$\mathrm{N}=\mathbf{2 5}$} & \multicolumn{2}{|c|}{$\mathbf{N}=\mathbf{3 7}$} & \multicolumn{2}{|c|}{$\mathrm{N}=\mathbf{2 9}$} & & \\
\hline & M & sd & M & sd & M & sd & M & sd & & \\
\hline Childcare & 3.43 & 0.68 & 3.52 & 0.50 & 3.37 & 0.68 & 3.33 & 0.55 & 0.437 & 0.727 \\
\hline Household & 3.64 & 0.82 & 3.84 & 0.74 & 3.51 & 0.76 & 3.58 & 0.62 & 0.980 & 0.401 \\
\hline $\begin{array}{l}\text { Psychological work } \\
\text { demands }\end{array}$ & 3.64 & 1.00 & 3.75 & 1.30 & 3.77 & 1.15 & 4.34 & 0.93 & 2.541 & 0.054 \\
\hline $\begin{array}{l}\text { Worktime organisation } \\
\text { effects }\end{array}$ & 3.00 & 1.43 & 4.90 & 0.93 & 4.84 & 1.42 & 4.95 & 1.31 & 17.32 & 0.000 \\
\hline Work-to-family conflict & 3.43 & 1.27 & 4.36 & 1.21 & 4.61 & 1.41 & 4.97 & 1.05 & 9.352 & 0.000 \\
\hline Family-to-work conflict & 1.94 & 0.78 & 1.72 & 0.76 & 2.28 & 1.52 & 2.15 & 1.35 & 1.316 & 0.272 \\
\hline My job (cogn.) & 3.70 & 1.62 & 2.34 & 1.11 & 2.66 & 1.57 & 2.81 & 1.52 & 4.371 & 0.006 \\
\hline My job (aff.) & 5.31 & 0.92 & 4.87 & 1.15 & 5.08 & 1.07 & 4.65 & 1.52 & 1.581 & 0.198 \\
\hline My family (cogn.) & 5.61 & 1.22 & 5.65 & 1.06 & 5.75 & 0.86 & 5.28 & 1.50 & 0.743 & 0.529 \\
\hline My family (aff.) & 6.40 & 0.57 & 6.58 & 0.43 & 6.50 & 0.58 & 6.18 & 0.81 & 1.890 & 0.135 \\
\hline My life (cogn.) & 4.72 & 1.40 & 4.53 & 1.27 & 4.56 & 1.50 & 4.40 & 1.71 & 0.225 & 0.879 \\
\hline My life (aff.) & 6.17 & 0.58 & 6.31 & 0.56 & 6.28 & 0.80 & 5.61 & 1.27 & 3.707 & 0.014 \\
\hline
\end{tabular}

Legend: Childcare - a 5-degree scale where 1 is 'completely the responsibility of my spouse' and 5 is 'completely my responsibility'; Household - a 5-degree scale where 1 is 'completely the responsibility of my spouse' and 5 is 'completely my responsibility'; Psychological work demands - a 7-degree scale with a higher result showing a higher level of negative work characteristics; Worktime organisation effects - a 7-degree scale with a higher result showing a higher level of negative effects of worktime on health, family, and social life; Work-to-family conflict-a 7-degree scale with a higher result showing a higher level of negative interference of work to family life; Family-to-work conflict-a 7-degree scale with a higher result showing a higher level of negative interference of family to work life; My job (cogn.) - a 7-degree scale with a higher result showing a higher level of the cognitive evaluative component of job satisfaction; My job (aff.) - a 7-degree scale with a higher result showing a higher level of the affective component of job satisfaction; My family (cogn.) - a 7-degree scale with a higher result showing a higher level of the cognitive evaluative component of family satisfaction; My family (aff.) - a 7-degree scale with a higher result showing a higher level of the affective component of job satisfaction; My life (cogn.) - a 7-degree scale with a higher result showing a higher level of the cognitive evaluative component of life satisfaction; My life (aff.) - a 7-degree scale with a higher result showing a higher level of the affective component of life satisfaction.

$M=$ mean

$s d=$ standard deviation

$F=$ F-ratio

rotating or irregular shifts scored it lower than other groups. This to some extent may reflect the differences in the level of negative effects of shift work on family life. It is likely that unpredictable distribution of working hours adversely affects functioning off work. This has partly been supported by Amelsvoort et al. (33), who have shown that backward rotating shift workers have a greater need for recovery, poorer health status, and poorer quality of sleep. In our earlier study (45), nurses in irregular and backward rotating shifts evaluated their health status as poorer than did the other groups of nurses.

\section{CONCLUSION}

This study is the first to investigate work-family interference among nurses from Croatia. In fact, no similar study has been performed in Croatian shift workers in general. It has shown that working three shifts is viewed as more difficult and stressing on other life domains. At the same time, the level of family-to-work conflict was very low in all four groups, which is in line with the findings in countries that highly value family as an institution (36). 
When it comes to satisfaction, the cognitiveevaluative component of job satisfaction was the highest in morning shift and the lowest in 12-hour shift nurses, while the affective component of life satisfaction was the highest in the morning shift and the lowest in nurses working irregular and backward rotating shifts. Family members and organisations of women working stressful jobs such as nurses should take into account the factors that may cause their higher fatigue and dissatisfaction and provide different types of support. Our findings can help to improve shift work efficiency and management. Working night, prolonged, and irregular shifts is obviously most stressful for working mothers. Since shift rotation and night work are almost inevitable in health institutions, organisations could at least minimise irregular shift work. The working time schedule should be determined and well known well in advance. In addition shiftwork schedules should allow a degree of flexibility to accommodate employee needs. Employees too could reduce adverse effects of shift work by maintaining a healthy lifestyle, which includes a healthy diet, exercise, and avoiding cigarettes and alcohol. They should also be more flexible about their priorities and try to shift a part of their traditional load to their partners.

\section{Limitations and future research}

The main limitation of this study is that the comparisons between nurses working shifts are obscured by different age of the groups. Another limitation is the small size of the groups compared, which renders interpretation of results less reliable and applicable in general.

Furthermore, the relative importance of family and work in the nurses' lives was not measured, which, for example, Carlson and Kacmar (46) found to be associated with the levels of work-to-family and family-to-work conflict and which may be important in interpreting our results.

We also have not taken into account worktime preferences and the morningness/eveningness type of personality in our nurses. Some people recover better after night shifts than others, and we believe that some of our nurses worked night shifts of their own choice.

It would have also been useful to include in the comparison a group of workers with morning and afternoon shifts or afternoon shifts alone to see whether night or afternoon shifts had a greater influence on the work-to-family conflict than the rest, as many family activities take place in the afternoon. Future research should address all these limitations.

\section{REFERENCES}

1. Yoder JD. Women and Gender: Transforming Psychology. $2^{\text {nd }}$ ed. Upper Saddle River (NJ): Prentice Hall; 2002.

2. Gerstel N, Sarkisian N. Sociological perspectives on families and work: the import of gender, class and race. In: PittCatsouphes M, Kossek E, Sweet S, editors. The work and family handbook: multidisciplinary perspectives, methods and approaches. Boston: Lawrence Earlbaum; 2006. p. 237 66.

3. Barnett RC, Shen Y-C. Gender, high- and low-schedulecontrol housework tasks, and psychological distress: a study of dual-earner couples. J Fam Issues 1997;18:403-28.

4. Lundberg U, Frankenhaeuser M. Stress and workload of men and women in high-ranking positions. J Occup Health Psychol 1999;4:142-51.

5. Bøggild H, Knutsson A. Shift work, risk factors and cardiovascular disease. Scand J Work Environ Health 1999;25:85-99.

6. Costa G. The impact of shift and night work on health. Appl Ergon 1996;27:9-16.

7. White J, Beswick J. Working long hours. Sheffield: Health and Safety Laboratory; 2003 [displayed 23 April 2012]. Available at http://www.hse.gov.uk/research/hsl_pdf/2003/ hs103-02.pdf

8. Wallace M. Shiftwork case studies. Asia Pac J Hum Resour 1983;21:43-6

9. Driscoll TR, Grunstein RR, Rogers NL. A systematic review of the neurobehavioural and physiological effects of shiftwork systems. Sleep Med Rev 2007;11:179-94.

10. Härmä M. Shift work among women - a century-old health issue in occupational health. Scand J Work Environ Health 2008;34:1-3.

11. Karlsson B, Knutsson A, Lindahl B. Is there an association between shift work and having a metabolic syndrome? Results from a population based study of 27485 people. Occup Environ Med 2001;58:747-52.

12. Rogers AE, Hwang W-T, Scott LD, Aiken LH, Dinges DF. Working hours of hospital staff nurses and patient safety. Health Affairs 2004;23:202-12.

13. Bonnefond A, Härmä M, Hakola T, Sallinen M, Kandolin I, Virkkala J. Interaction of age with shift-related sleepwakefulness, sleepiness, performance, and social life. Exp Aging Res 2006;32:185-208.

14. Härmä M, Tenkanen L, Sjöblom T, Alikoski T, Heinsalmi P. Combined effects of shiftwork and life-style on the prevalence of insomnia, sleep deprivation and daytime sleepiness. Scand J Work Environ Health 1998;4:300-7.

15. Kolstad H. Nightshift work and risk of breast cancer and other cancers-a critical review of the epidemiologic evidence. Scand J Work Environ Health 2008;34:5-22.

16. Samaha E, Lai S, Samaha N, Wyndham J. Psychological, lifestyle and coping contributors to chronic fatique in shiftworker nurses. J Adv Nurs 2007;59:221-32.

17. Knauth P. Extended work periods. Ind Health 2007;45:12536. 
18. Frone MR, Russell M, Cooper ML. Antecedents and outcomes of work-family conflicts: testing a model of workfamily interface. J Appl Psychol 1992;77:65-75.

19. Frone MR, Yardley JK, Markel KS. Developing and testing an integrative model of the work-family interface. J Vocat Behav 1997;50:145-67.

20. Staines GL, Pleck JH. The Impact of Work Schedules on the Family. Ann Arbor (MI): University of Michigan Press; 1983.

21. Fenwick R, Tausig M. Scheduling stress family and health outcomes of shift work and schedule control. Am Behav Sci 2001;44:1179-98.

22. Tausig M, Fenwick R. Unbinding time: alternative work schedules and work-life balance. J Family Econ Issues 2001;22:101-19.

23. Kinnunen U, Mauno S. Antecedents and outcomes of work family conflict among employed women and men in Finland. Hum Relat 1998;51:157-77.

24. MacEwen KE, Barling J. Interrole conflict, family support and marital adjustment of employed mothers: A short-term longitudinal study. J Organ Behav 1988;9:241-50.

25. Hill EJ, Yang C, Hawkins AJ, Ferris M. A cross-cultural test of the work-family interface in 48 countries. J Marriage Fam 2004;66:1300-16.

26. Voydanoff P. The differential salience of family and community demands and resources for family-to-work conflict and facilitation. J Family Econ Issues 2005;26:395417.

27. Jansen NWH, Kant I, Nijhuis FJN, Swaen GMH, Kristensen TS. Impact of worktime arrangements on work-home interference among Dutch employees. Scand J Work Environ Health 2004;30:139-48.

28. Hakola T, Härmä M. Evaluation of a fast forward rotating shift schedule in the steel industry with a special focus on ageing and sleep. J Hum Ergol 2003;30:315-19.

29. Hakola T, Paukkonen M, Pohjonen T. Less quick returns greater well-being. Ind Health 2010;48:390-4.

30. Härmä M, Tarja H, Irja K, Mikael S, Jussi V, Anne B, Pertti $\mathrm{M}$. A controlled intervention study on the effects of a very rapidly forward rotating shift system on sleep-wakefulness and well-being among young and elderly shift workers. Int J Psychophysiol 2006;59:70-9.

31. Viitasalo K, Kuosma E, Laitinen J, Härmä M. Effects of shift rotation and the flexibility of a shift system on daytime alertness and cardiovascular risk factors. Scand J Work Environ Health 2008;34:198-205.

32. Grosswald B. Shift work and negative work-to-family spillover. J Sociol Soc Welf 2003 [displayed 23 April 2012].
Available at http://findarticles.com/p/articles/mi_m0CYZ/ is 4 30/ai_111933182/

33. van Amelsvoort LG, Jansen NWH, Swaen GMH, van der Brandt PA, Kant I. Direction of shift rotation among threeshift workers in relation to psychological health and workfamily conflict. Scand J Work Environ Health 2004;30:14956.

34. Barnett RC, Gareis KC, Brennan RT. Wives' shift work schedules and husbands' and wives' well-being in dual earner couples with children. J Fam Issues 1992;29:396-422.

35. Yildirim D, Aycan Z. Nurses' work demands and work-family conflict: A questionnaire survey. Int J Nurs Stud 2008;45:136678.

36. European NEXT-Study [displayed 23 April 2012]. Available at http://www.next.uni-wuppertal.de/EN/index. php?articles-and-reports

37. Ahasan R, Mohiuddin G, Khaleque A. Psychosocial implications of shift work: a case study. Work Study 2002;51:116-20.

38. Netemeyer RG, Boles JS, McMurrian R. Development and validation of work-family conflict scales and family-work conflict scales. J Appl Psychol 1996;81:400-10.

39. Gregov Lj. Nametnuti ritam rada kao stresor [Paced work rhythm as a stressor; in Croatian]. [Master thesis]. Zagreb: Faculty of Phylosophy, University in Zagreb; 1994.

40. Parkes KR. Shift work and age as interactive predictors of body mass index among offshore workers. Scand J Work Environ Health 2002;28:64-71.

41. Costa G. Factors influencing health of workers and tolerance to shift work. Theor Issues Ergon Sci 2003;4:263-88.

42. Mitchell RJ, Williamson AM. Evaluation of an 8 hour versus a 12 hour shift roster on employees at a power station. Appl Ergon 2000;31:83-9.

43. Mott PE, Mann FC, McLoughlin Q, Warwick DP. Shift work: The social, psychological, and physical consequences. Ann Arbor (MI): University of Michigan Press; 1965.

44. Šimunić A, Rupić L, Gregov Lj, Šimić N. Organizacija smjenskog rada, zadovoljstvo poslom i zdravstveni status kod medicinskih sestara [Shift work organization, job satisfaction, and health status in nurses; in Croatian]. In: Vulić-Prtorić A, Ćubela Adorić V, Proroković A, Sorić I, Valerjev P, editors. Book of Abstracts of the XVI. Psychology Days in Zadar; 29-31 May 2008; Zadar, Croatia. Zadar: Department of Psychology, University in Zadar; 2008. p. 109.

45. Carlson D, Kacmar L. Work-family conflict in the organization: do life role values make a difference? J Manage 2000;26:1031-54 


\section{Sažetak \\ SUKOB RADNIH I OBITELJSKIH ULOGA I ZADOVOLJSTVA U MEDICINSKIH SESTARA U HRVATSKOJ S RAZLIČITIM SUSTAVIMA SMJENSKOGA RADA}

Cilj je ovoga istraživanja bio ispitati percepciju sukoba između radnih i obiteljskih uloga i radno, obiteljsko i životno zadovoljstvo kod medicinskih sestara s obzirom na različite vrste organizacije radnoga vremena. 129 udatih medicinskih sestara majki koje rade u bolnicama u Zadru, Šibeniku i Splitu podijeljeno je u 4 skupine s obzirom na vrstu organizacije radnoga vremena. Sudionice su ispunile upitnik koji je uključivao set pitanja sociodemografskoga tipa, pitanja o količini i raspodjeli obiteljskih odgovornosti među supružnicima i skale koje mjere percipirane negativne efekte radnoga vremena, psihološke zahtjeve posla, sukob između radne i obiteljske uloge te skale semantičkoga diferencijala za mjerenje afektivne i kognitivnoevaluativne komponente radnog i obiteljskog zadovoljstva i života općenito. Ovo je prvo istraživanje provedeno u Hrvatskoj u kojem je ispitivan sukob radne i obiteljske uloge kod medicinskih sestara ili općenito radnika s različitim sustavima smjenskoga rada.

Rezultati pokazuju da sestre koje rade u stalnim jutarnjim smjenama doživljavaju manje sukoba zbog ometajućih utjecaja rada na obitelj od grupe medicinskih sestara koje su radile u tri smjene (u koje je uključena noćna smjena). Kognitivno-evaluativna komponenta zadovoljstva poslom bila je najviša kod medicinskih sestara s jutarnjim smjenama, a najniža kod onih koje su radile u 12-satnim smjenama. Afektivna komponenta zadovoljstva životom bila je najniža kod medicinskih sestara koje su radile u iregularnim i unatrag rotiranim smjenama. Ovi su rezultati dodatan pokazatelj različitih i više ili manje negativnih efekata smjenskoga rada na sukob između radnih i obiteljskih uloga te dodatno upozoravaju na važnost uzimanja u obzir vrste rotacije smjena.

KLJUČNE RIJEČI: smjenski rad, sukob radne i obiteljske uloge, zadovoljstvo obiteljskim životom, zadovoljstvo poslom, životno zadovoljstvo

\section{CORRESPONDING AUTHOR:}

Ana Šimunić

Department of Psychology, University of Zadar

Obala Kralja Petra Krešimira IV., 2, Zadar, Croatia

E-mail:asimunic@unizd.hr 